\title{
Benomyl Sensitivity of Isolates of Colletotrichum acutatum and $C$. gloeosporioides from Citrus
}

N. A. R. Peres, former Ph.D. student, and N. L. Souza, Professor, Universidade Estadual Paulista, FCA, Botucatu, SP, 18603-970, Brazil; T. L. Peever, Assistant Professor, Washington State University, Pullman 99164-6430, and L. W. Timmer, Professor, University of Florida, Citrus Research and Education Center, Lake Alfred 33850

\begin{abstract}
Peres, N. A. R., Souza, N. L., Peever, T. L., and Timmer, L. W. 2004. Benomyl sensitivity of isolates of Colletotrichum acutatum and C. gloeosporioides from citrus. Plant Dis. 88:125-130.

Postbloom fruit drop (PFD) of citrus, caused by Colletotrichum acutatum, produces orangebrown lesions on petals and results in premature fruit drop and the retention of calyces. C. gloeosporioides is common in groves and causes postharvest anthracnose on fruit. Both diseases are controlled effectively by the fungicide benomyl in research fields and commercial orchards. Highly sensitive and resistant isolates of $C$. gloeosporioides were found, whereas all isolates of $C$. acutatum tested were moderately resistant. In preliminary studies conducted in vitro with three isolates of each, mycelial growth of sensitive isolates of $C$. gloeosporioides was inhibited completely by benomyl (Benlate $50 \mathrm{WP}$ ) at $1.0 \mu \mathrm{g} / \mathrm{ml}$, whereas resistant isolates grew well at 10 $\mu \mathrm{g} / \mathrm{ml}$. Growth of all isolates of $C$. acutatum was inhibited by about $55 \%$ at $0.1 \mu \mathrm{g} / \mathrm{ml}$ and by $80 \%$ at $1.0 \mu \mathrm{g} / \mathrm{ml}$. Spore germination of C. acutatum was inhibited more at $0.1 \mu \mathrm{g} / \mathrm{ml}$ than at 1.0 $\mu \mathrm{g} / \mathrm{ml}$ or higher concentrations. In all, 20 isolates of C. acutatum from 17 groves and 20 isolates of $C$. gloeosporioides from 7 groves were collected from locations with different histories of benomyl usage in São Paulo, Brazil, and Florida, United States. Benomyl at $1.0 \mu \mathrm{g} / \mathrm{ml} \mathrm{com-}$ pletely inhibited growth of 133 isolates of $C$. gloeosporioides, with the exception of 7 isolates that were highly resistant to the fungicide, whereas all isolates of $C$. acutatum were only partially inhibited at 0.1 and $1.0 \mu \mathrm{g} / \mathrm{ml}$. Analysis of variance indicated that the sensitivity of the isolates of $C$. acutatum was not affected by benomyl usage or grove of origin, and country of origin had only minor effects. No highly resistant or sensitive isolate of $C$. acutatum was recovered. Partial sequencing of the $\beta$-tubulin gene did not reveal nucleotide substitutions in codons 198 or 200 in C. acutatum that usually are associated with benomyl resistance in other fungi.
\end{abstract}

Postbloom fruit drop (PFD), caused by Colletotrichum acutatum J. H. Simmonds, is characterized by orange-brown lesions on petals of citrus flowers and results in the abscission of fruitlets $(20,21)$. The pathogen is widely distributed in the humid tropics of the Americas and serious losses may occur in Florida (United States) and São Paulo (Brazil) when rains occur during the bloom period (13). Postharvest anthracnose is caused by $C$. gloeosporioides and is a problem especially for fruit harvested early that must be de-

Corresponding author: N. A. R. Peres E-mail: narperes@webcable.com.br

Current address of N. A. R. Peres: Instituto Biológico, Av. Conselheiro Rodrigues Alves 1252, São Paulo, SP, Brazil, 04014-002.

This research was supported by the Florida Agricultural Experiment Station and approved for publication as Journal Series No. R-09228.

This research was supported in Brazil by the Fundação de Amparo a Pesquisa do Estado de São Paulo.

Accepted for publication 21 August 2003.

Publication no. D-2003-1117-02R

(C) 2004 The American Phytopathological Society greened with ethylene. C. gloeosporioides also is a common saprophyte in citrus groves (22).

Benomyl is one of the most effective fungicides for control of PFD and postharvest anthracnose of citrus $(14,18,23)$. However, C. acutatum isolates from citrus are inherently much less sensitive to benomyl in culture than other plant-pathogenic fungi $(6,14,17)$. In contrast, most isolates of $C$. gloeosporioides are completely inhibited by benomyl at $1 \mu \mathrm{g} / \mathrm{ml}$ in culture. Benomyl has protective and eradicative activity against pathogens of various crops. In previous studies, we demonstrated that benomyl acted by inhibiting mycelial growth of $C$. acutatum in petal tissue and had postinfectional activity up to $48 \mathrm{~h}$ after inoculation, but did not kill conidia or prevent conidial germination (14).

Benzimidazoles are specific inhibitors of microtubule assembly that act by binding to their heterodimeric subunit, the tubulin molecule (5). Benzimidazole fungicides have a very specific mode of action; therefore, the development of benomyl resistance is a major concern in disease management (9). Benomyl has been used in agriculture for approximately 30 years and numerous cases of resistance have been reported, including Colletotrichum spp. on various crops as well as other fun- gal pathogens of citrus $(8,25,26)$ and other crops $(9,10,15,27)$.

Sequence analysis of the $\beta$-tubulin gene of benomyl-resistant fungi revealed that resistance almost always is due to a mutation of a single nucleotide that results in a single amino acid change at codons 198 or 200. Amino acid substitutions at these two codon positions result in different benomyl-resistance phenotypes $(1,27)$. For example, with Venturia inaequalis, mutants with substitutions at position 198, from glutamic acid to lysine, glycine, or alanine, have high or very high level of resistance, and mutants with a substitution of phenylalanine by tyrosine in position 200 have moderate levels of benomyl resistance (10).

Problems with control of PFD never have been documented despite the fact that many fungi have developed resistance to benomyl and there has been widespread use of benomyl on citrus, including in Brazil and the United States. Mixtures of benomyl with contact fungicides such as ferbam, folpet, or mancozeb currently are recommended (19) to manage resistance, but many growers apply benomyl alone. The objectives of this research were to (i) compare the activity of benomyl for $C$. acutatum and $C$. gloeosporioides in vitro, (ii) survey groves in São Paulo and Florida to determine the effect of benomyl usage on the sensitivity of fungal isolates, and (iii) determine whether typical resistance sequences of the $\beta$-tubulin gene occur in C. acutatum.

\section{MATERIALS AND METHODS}

Isolate collection and culture. Isolates of $C$. acutatum were obtained from infected petals of sweet orange and those of C. gloeosporioides from dead twigs and leaves in Florida and São Paulo. An additional isolate of $C$. gloeosporioides was obtained from blueberry in Florida. Isolations were made by cutting small sections from the leading edges of flower lesions or from asymptomatic leaf tissues, wetting the sections briefly (30 s) in $95 \%$ ethanol, surface disinfesting in $1 \% \mathrm{NaOCl}(1 \mathrm{~min})$, and rinsing in sterile distilled water. Sections were placed on potato-dextrose agar (PDA) and incubated at $24^{\circ} \mathrm{C}$ with a $12-\mathrm{h}$ photoperiod. All isolates were allowed to colonize sterile filter papers and maintained as dried cultures in sealed plastic containers with $\mathrm{CaSO}_{4}$ desiccant at $-20^{\circ} \mathrm{C}$ 
as previously described (12). Cultures were grown routinely on PDA at $24^{\circ} \mathrm{C}$ for production of mycelial plugs and conidia.

Benomyl sensitivity assays. The critical discriminatory concentrations of benomyl for $C$. acutatum, sensitive $C$. gloeosporioides, and resistant C. gloeosporioides were determined in a preeach collected in Florida. Cultures of $C$. acutatum (isolates CS-1, Maran, and Mayo), C. gloeosporioides sensitive (isolates GND-1, TH-4, and Dil-Ark-1), and C. gloeosporioides laboratory-selected resistant (isolates GND-1 [R], TH-4 [R], and Dil-Ark-1 $[\mathrm{R}]$ ) were grown on PDA for 1 week, and 0.5 -cm-diameter mycelial plugs were cut from the margins of the colony with a cork borer. Plugs were transferred to three plates each of PDA amended with benomyl (Benlate $50 \mathrm{WP}$; DuPont, Wilmington, DE) at 0, 0.1, 1, 10, 100 , or $1,000 \mu \mathrm{g}$ a.i./ml. Plates were incubated for 1 week at $24^{\circ} \mathrm{C}$ under a 12 -h photoperiod. The radius of the colony was measured and the area calculated and data expressed as percentage of the control.

The effect of benomyl concentrations on conidial germination was determined for isolates IM-2, GL-Pike, and SGR-FTP-1 of $C$. acutatum. Conidia of each isolate were harvested from PDA cultures in sterile distilled water and the conidial suspension was adjusted to a final concentration of $5 \times 10^{2}$ conidia/ml. A volume of $100 \mu \mathrm{l}$ was spread on the surface of three replicate plates with PDA containing benomyl at 0 , 0.1 , and $1 \mu \mathrm{g}$ a.i./ml. Plates were incubated at $24^{\circ} \mathrm{C}$ for 3 days with a 12 -h photoperiod. The number and size of colonies that developed were measured and data expressed as percentage of control. The experiment was conducted four times in a similar manner, but colony area was measured in only three of the experiments. Another experiment was conducted once with the same isolates with benomyl at $0,0.1,1$, 10,100 , and $1,000 \mu \mathrm{g}$ a.i./ml. liminary experiment using three isolates of

Sensitivity of isolates from citrus groves with different histories of benomyl use. Twenty isolates of $C$. acutatum were collected from each of 17 groves of sweet orange (Citrus sinensis (L.) Osbeck) in São Paulo and Florida that had received four different frequencies of benomyl usage. The groves used were planted to the following cultivars: Pera (FZR-PRD, FSHMGG, SLG-MGG, CIA-BTU, and CITCA-ITP), Natal (SFL-MGG and CTPITP), Valencia (FSH-CLB, VTP-IND, CLR-IMK, RCO-IMK, MRN-IND, ALBIND, and STF-FTP) or Navel orange (SRL-FTP, SGR-FTP, and OCO-ARC). In "high-use" groves, benomyl was applied every year, often 2 to 3 times per year; in "moderate-use" groves, benomyl was applied in most years, but usually not more than once per year; in "low-use" groves, benomyl was sprayed from one to three times during the last 5 years; and "no-use" groves had no known applications of the fungicide. To the extent possible, each isolate was collected from a different tree in the grove. In addition, 20 isolates of Colletotrichum gloeosporioides were recovered from asymptomatic leaves from seven of the groves studied. Cultures of $C$. acutatum and $C$. gloeosporioides were grown on PDA for 1 week and $0.5-\mathrm{cm}$ diameter mycelial plugs were cut from the margins of the colony. Plugs of each isolate were transferred to the center of three petri dishes each of PDA containing benomyl at $0,0.1$, and $1.0 \mu \mathrm{g}$ a.i./ml. Cultures were incubated for 1 week at $24^{\circ} \mathrm{C}$ with a 12-h photoperiod. The sensitivity assay for each isolate was conducted twice. Colony radius was measured, and the area calculated and expressed as a percentage of the control. The effects of benomyl usage, country, grove, assay, and the interaction of all factors were determined by analysis of variance using the GLM procedure in SAS (SAS Institute, Cary, NC). The mean square was divided by the appropriate error term in each case and type III sum of

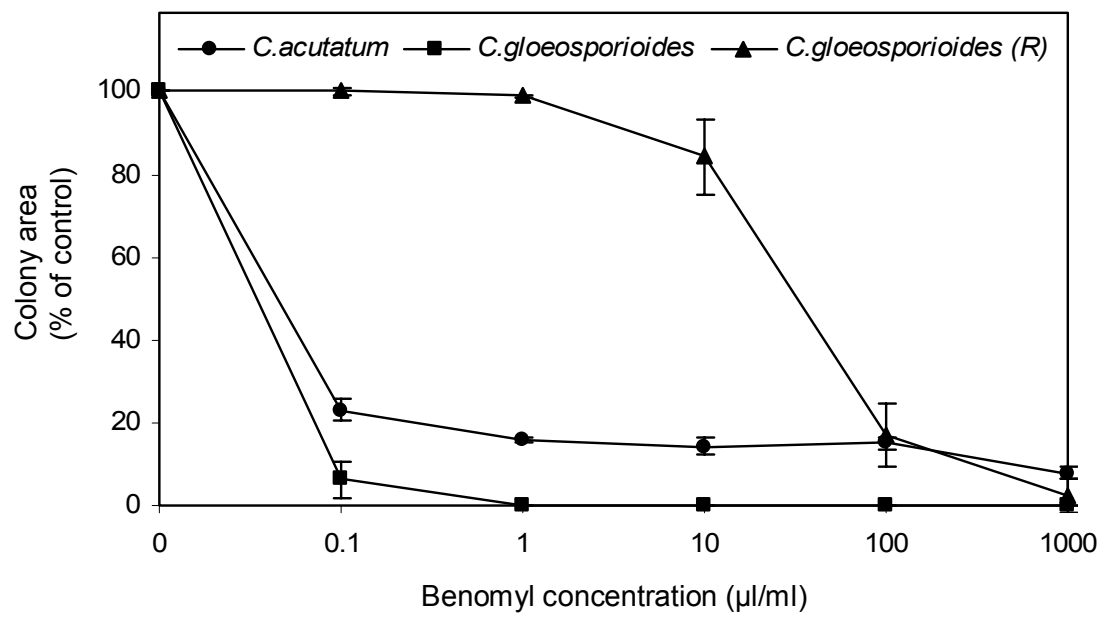

Fig. 1. Effect of benomyl at different concentrations on the colony area of three isolates of Colletotrichum spp. in culture ( $\mathrm{R}=$ resistant). square values were used to calculate $F$ values.

Partial sequencing of the $\beta$-tubulin gene. Fungal culture and DNA extraction. Twelve isolates were selected to represent different benomyl resistance phenotypes. These included (i) four isolates of $C$. $a c u$ tatum moderately resistant to benomyl, (ii) three isolates of C. gloeosporioides highly sensitive to benomyl, (iii) two isolates of C. gloeosporioides field-resistant to benomyl, and (iv) three laboratory-selected resistant isolates of $C$. gloeosporioides. For selection of resistant isolates of $C$. gloeosporioides, a volume of $100 \mu \mathrm{l}$ of a conidial suspension of 50 conidia/ml was spread on the surface of PDA amended with benomyl at $1 \mu \mathrm{g}$ a.i./ml. Conidia were incubated at $24^{\circ} \mathrm{C}$ for 3 days and the colonies that developed were selected. For production of mycelium, isolates were grown for 4 days in potato dextrose broth on a rotary shaker and the mycelium was collected and lyophilized as previously described (12). Genomic DNA was extracted from $50 \mu \mathrm{g}$ of lyophilized mycelium (12). DNA concentrations were estimated visually in $0.7 \%$ ethidium bromidestained agarose gels by comparing band intensity with know quantities of lambda DNA/HindIII markers (Promega Corp., Madison, WI).

Primer design and PCR amplification. Primers TB2L (5'-GYTTCCAGATYACCCACTCC-3') and TB2R (5'-TGAGCTCAGGAACRCTGACG-3') were designed using Primer3 software to amplify a portion of the $\beta$-tubulin gene where benomylresistance mutations in field-collected isolates usually occur $(10,27)$. Primer TB2L was designed to prime at nucleotide positions 1,133 to 1,152 and primer TB2R was designed to prime at nucleotide positions 1,606 to 1,625 , both relative to a $\beta$ tubulin sequence of $C$. gloeosporioides $\mathrm{f}$. sp. aeschynomene (GenBank accession U14138). Amplification of partial $\beta$-tubulin sequences was carried out in a total reaction volume of $25 \mu \mathrm{l}$. Polymerase chain reaction $(\mathrm{PCR})$ reaction mixtures contained $10 \mathrm{ng}$ of DNA, $2.5 \mathrm{ml}$ of $1 \times$ PCR buffer (Promega Corp.), $2.0 \mathrm{mM}$ $\mathrm{MgCl}_{2}$ (Promega Corp.), $200 \mu \mathrm{M}$ dNTPs (Idaho Technologies, Idaho Falls, ID), 0.3 $\mu \mathrm{M}$ each primer (Operon Technologies, Alameda, CA), and 1 unit of Taq polymerase (Promega Corp.). All PCR reactions were carried out in an Omn-E thermal cycler (Hybaid, Ashford, Middlesex, $\mathrm{UK}$ ) with a hold of $2 \mathrm{~min}$ at $95^{\circ} \mathrm{C}$, followed by 40 cycles of $1 \mathrm{~min}$ at $95^{\circ} \mathrm{C}, 1$ min at $55^{\circ} \mathrm{C}$, and $1 \mathrm{~min}$ at $72^{\circ} \mathrm{C}$, and a final extension for $5 \mathrm{~min}$ at $72^{\circ} \mathrm{C}$. PCR products were separated by electrophoresis on $1 \%$ agarose gels (Life Technologies, Grand Island, NY) with 100-bp ladder (Promega Corp.) as a size standard.

DNA sequencing. Amplicons corresponded to nucleotide positions 1,141 to 1,619 of the $\beta$-tubulin sequence of $C$. 
gloeosporioides f. sp. aeschynomene (GenBank accession U14138). Amplicons were purified through QiaQuick PCR purification columns (Qiagen, Valencia, CA) according to the manufacturer's instructions. Purified PCR products were direct-sequenced on both strands using cycle sequencing with TB2R and TB2L primers. Each sequence reaction contained 40 to 90 ng of DNA, $3.2 \mathrm{mM}$ primer, $4 \mu \mathrm{l}$ BigDye Terminator (Applied Biosystems, Foster City, CA), and sterile distilled water in 10$\mu \mathrm{l}$ total volumes. Reactions were performed in an Omn E-thermal cycler (Hybaid) and cycling conditions consisted of 25 cycles of $15 \mathrm{~s}$ at $96^{\circ} \mathrm{C}, 15 \mathrm{~s}$ at $50^{\circ} \mathrm{C}$, and $4 \mathrm{~min}$ at $60^{\circ} \mathrm{C}$. Sequences were read in a PE Biosystems Model 377 Automated DNA Sequencer (Applera Corporation, Norwalk, CT). All sequencing was performed in the Laboratory for Biotechnology and Bioanalysis, School of Molecular Biosciences, Washington State University.

\section{RESULTS}

Fungicide-sensitive assays. Colony area of $C$. acutatum isolates was reduced to about $25 \%$ of the control at $0.1 \mu \mathrm{g} / \mathrm{ml}$ and to about $15 \%$ of the control at $1 \mu \mathrm{g} / \mathrm{ml}$, but higher concentrations of the fungicide concentration did not further reduce growth (Fig. 1). In contrast, the colony area of benomyl-sensitive $C$. gloeosporioides isolates was reduced to about $8 \%$ of the control at $0.1 \mu \mathrm{g} / \mathrm{ml}$ and growth was completely inhibited at higher concentrations. Benomyl-resistant C. gloeosporioides isolates were unaffected by concentrations lower than $10 \mu \mathrm{g} / \mathrm{ml}$ and growth was about 20 and $10 \%$ of the control at 100 and $1,000 \mu \mathrm{g} / \mathrm{ml}$, respectively.

Analyses of variance demonstrated that conidial germination was significantly lower at the lower concentration (Table 1). Some variation was observed among experiments, but conidial germination was higher at the higher fungicide concentrations in all experiments with all isolates. In contrast to conidial germination, radial growth of mycelium did not differ signifi- cantly between the two concentrations evaluated (Table 1). There were no significant differences among isolates with regard to conidial germination or radial growth. In another experiment, germination of conidia at the lowest concentration of $0.1 \mu \mathrm{g} / \mathrm{ml}$ was similar to germination at higher concentrations up to $1,000 \mu \mathrm{g} / \mathrm{ml}$ (Fig. 2). The highest percentage of germination was recorded at the intermediary concentration of $10 \mu \mathrm{g} / \mathrm{ml}$. The effect of benomyl on colony area from germinated spores (Fig. 2) was similar to the effect observed on the colony area from mycelial plugs (Fig. 1) (i.e., despite the fact that the fungicide reduced colony area to $20 \%$ of the control at $1.0 \mu \mathrm{g} / \mathrm{ml}$, higher concentrations did not completely inhibit growth).

Sensitivity of isolates from citrus groves with different histories of benomyl use. Isolates of $C$. acutatum from groves with different histories of benomyl use showed similar levels of benomyl sensitivity (Table 2). The mean colony area across all isolates was reduced to approximately $42 \%$ of the control at $0.1 \mu \mathrm{g} / \mathrm{ml}$ and to about $20 \%$ of the control at $1.0 \mu \mathrm{g} / \mathrm{ml}$ (Table 2). Benomyl usage history was not a significant factor in the analysis at either 0.1 or $1.0 \mu \mathrm{g} / \mathrm{ml}$ (Table 3 ). Country was a significant factor at $1.0 \mu \mathrm{g} / \mathrm{ml}$ but not at 0.1 $\mu \mathrm{g} / \mathrm{ml}$. The mean relative colony growth at $1.0 \mu \mathrm{g} / \mathrm{ml}$ was $22.4 \%$ for Brazil and $19.8 \%$ for Florida. There was no significant interaction between benomyl usage and country at either fungicide concentration. Grove was not a significant factor at either concentration, and assay was not significant at $0.1 \mu \mathrm{g} / \mathrm{ml}$, but was marginally significant at $1.0 \mu \mathrm{g} / \mathrm{ml}$ (Table 3). There was a highly significant interaction of grove and assay, probably because assays were conducted in different locations. However, differences between assays were small. The average growth was 20.3 and $21.9 \%$ of the control for the first and second assay, respectively, at $0.1 \mu \mathrm{g} / \mathrm{ml}$. At $1.0 \mu \mathrm{g} / \mathrm{ml}$, the average for the first assay was $43.3 \%$ and for the second assay was $44.0 \%$ of the control. There was no significant interaction between assay and benomyl usage or country and the three-way interaction was not significant at either 0.1 or $1.0 \mu \mathrm{g} / \mathrm{ml}$ (Table 3).

No highly resistant or highly sensitive isolate was detected among the $340 \mathrm{C}$. acutatum isolates evaluated in this study. The analysis of variance indicated that individual isolates of $C$. acutatum within grove varied significantly in response to

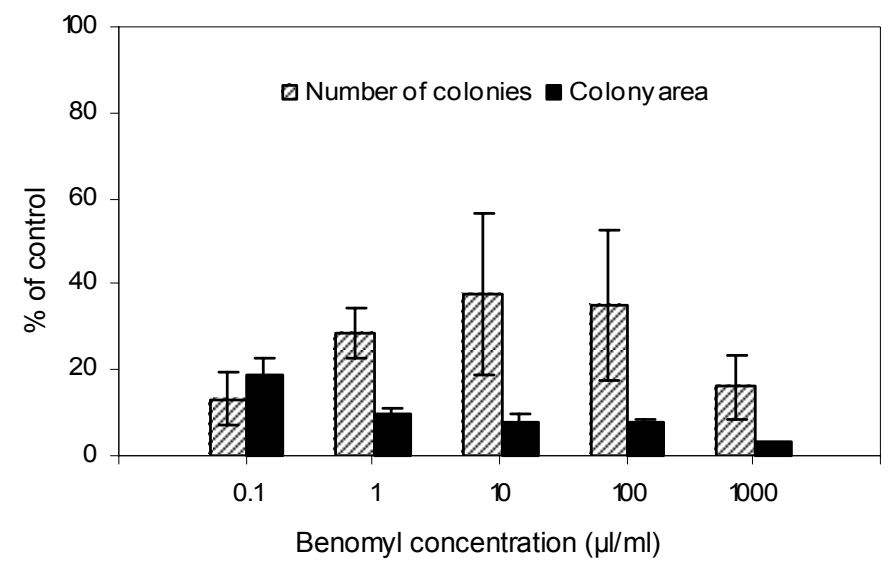

Fig. 2. Effect of different concentrations of benomyl on the germination and growth of conidia of Colletotrichum acutatum.

Table 1. Effect of benomyl on the germination of conidia and colony size of Colletotrichum acutatum isolates from citrus

\begin{tabular}{|c|c|c|c|c|c|c|c|c|c|c|}
\hline \multirow[b]{3}{*}{ Conc., isolate $\mathrm{e}^{\mathrm{a}}$} & \multicolumn{5}{|c|}{ Germination ( $\%$ of control) } & \multicolumn{5}{|c|}{ Colony area (\% of control) } \\
\hline & \multicolumn{4}{|c|}{ Experiment } & \multirow[b]{2}{*}{ Mean $^{b}$} & \multicolumn{4}{|c|}{ Experiment } & \multirow[b]{2}{*}{ Mean $^{b}$} \\
\hline & 1 & 2 & 3 & 4 & & 1 & 2 & 3 & 4 & \\
\hline \multicolumn{11}{|l|}{$0.1 \mu \mathrm{g} / \mathrm{ml}$} \\
\hline IM-2 & 3 & 24 & 17 & 14 & 14.5 & 11 & $\mathrm{ND}^{\mathrm{c}}$ & 5 & 27 & 14.3 \\
\hline GL- Pike & 15 & 23 & 4 & 7 & 11.9 & 23 & ND & 1 & 7 & 10.2 \\
\hline \multirow[t]{2}{*}{ SGR-FTP-1 } & 15 & 29 & 23 & 19 & 21.5 & 37 & ND & 3 & 22 & 20.7 \\
\hline & $\ldots$ & $\ldots$ & $\ldots$ & $\ldots$ & $16.0 *$ & $\ldots$ & $\ldots$ & $\ldots$ & $\ldots$ & $15.0 \mathrm{NS}$ \\
\hline \multicolumn{11}{|l|}{$1.0 \mu \mathrm{g} / \mathrm{ml}$} \\
\hline IM-2 & 52 & 45 & 49 & 23 & 42.4 & 21 & ND & 6 & 13 & 13.3 \\
\hline GL- Pike & 49 & 102 & 77 & 35 & 65.8 & 49 & ND & 2 & 5 & 18.8 \\
\hline \multirow[t]{2}{*}{ SGR-FTP-1 } & 56 & 42 & 54 & 28 & 45.0 & 32 & ND & 5 & 12 & 16.0 \\
\hline & $\ldots$ & $\ldots$ & $\ldots$ & $\ldots$ & 51.0 & $\ldots$ & $\ldots$ & $\ldots$ & $\ldots$ & 16.0 \\
\hline
\end{tabular}

\footnotetext{
${ }^{\text {a }}$ Conc. $=$ benomyl concentration.
}

$\mathrm{b}$ There were no significant differences among isolates within concentrations. NS $=$ no significant differences between concentrations and $*=$ significant differences between concentrations based on a $t$ test at $\alpha=0.05$.

c ND = not determined. 
benomyl for grove SRL-FTP $(P=0.0023)$ and for grove SLG-MGG $(P=0.0093)$, but the range of variability was small (Fig. 3 ). In contrast, individual isolates of $C$. gloeosporioides within grove varied significantly in response to benomyl at both concentrations $(P<0.0001)$, with complete inhibition of all but a few isolates.

Partial sequencing of the $\beta$-tubulin gene. Amplification of a portion of the $\beta$ tubulin gene with primers TB2R and TB2L produced amplicons of $457 \mathrm{bp}$ for all tested isolates. Alignment of the sequences revealed 21 polymorphic nucleotide sites separating $C$. acutatum and $C$. gloeosporioides species (data not shown). Three isolates of C. gloeosporioides resistant to benomyl contained a single mutation, an A-to-C transition at nucleotide 1,331 , resulting in a substitution of glutamic acid by alanine at amino acid 198 (Table 4). No substitutions were observed in any of the isolates at codon 200 .

\section{DISCUSSION}

C. acutatum and C. gloeosporioides differed greatly in their sensitivity to benomyl. Most isolates of C. gloeosporioides were highly sensitive, but resistance appears to develop very rapidly to this pathogen. In this study, we recovered several isolates of C. gloeosporioides that had high levels of resistance, even though we sampled fewer isolates of C. gloeosporioides than of $C$. acutatum. Resistant isolates of $C$. gloeosporioides even were recovered from groves where benomyl was not known to be used. Koenraadt and Jones (10) collected some benomyl-resistant field strains of $V$. inaequalis in an orchard more than 10 years after benomyl had been discontinued. In contrast, all the isolates of C. acutatum we tested were only moderately resistant to benomyl and $\geq 1.0 \mu \mathrm{g} / \mathrm{ml}$ reduced colony area by about $80 \%$. We found no isolates of $C$. acutatum that were as resistant or as sensitive as isolates of $C$.

Table 2. Effect of benomyl on the in vitro growth of isolates of Colletotrichum acutatum from citrus groves with different histories of usage of benomyl

\begin{tabular}{|c|c|c|c|c|}
\hline \multirow[b]{2}{*}{ Usage $^{b}$} & \multirow[b]{2}{*}{ Isolate } & \multirow[b]{2}{*}{ Location $^{\mathrm{c}}$} & \multicolumn{2}{|c|}{ Colony area $(\% \text { of control })^{a}$} \\
\hline & & & 0.1 & 1.0 \\
\hline \multirow[t]{4}{*}{ None } & FZR-PRD-(1 to 20) & Pardinho, SP, Brazil & 41.5 & 21.2 \\
\hline & FSH-CLB-( 1 to 20$)$ & Colômbia, SP, Brazil & 45.7 & 23.4 \\
\hline & VTP-IND-(1 to 20$)$ & Indiantown, FL, USA & 39.9 & 17.7 \\
\hline & SRL-FTP- $(1$ to 20$)$ & Frostproof, FL, USA & 44.8 & 19.9 \\
\hline Mean & $\ldots$ & $\ldots$ & 43.0 & 20.5 \\
\hline \multirow[t]{6}{*}{ Low } & CIA-BTU-(1 to 20$)$ & Botucatu, SP, Brazil & 43.5 & 23.8 \\
\hline & FSH-MGG-(1 to 20$)$ & Mogi Guaçu, SP, Brazil & 39.3 & 22.3 \\
\hline & CLR-IMK-(1 to 20$)$ & Immokalee, FL, USA & 42.9 & 19.6 \\
\hline & RCO-IMK-(1 to 20$)$ & Immokalee, FL, USA & 47.5 & 20.4 \\
\hline & MRN-IND-( 1 to 20$)$ & Indiantown, FL, USA & 39.4 & 18.7 \\
\hline & ALB-IND- $(1$ to 20$)$ & Indiantown, FL, USA & 37.9 & 18.4 \\
\hline Mean & $\ldots$ & $\ldots$ & 41.7 & 21.2 \\
\hline \multirow[t]{4}{*}{ Moderate } & CIT-ITP-(1 to 20$)$ & Itapetininga, SP, Brazil & 38.8 & 19.5 \\
\hline & SFL-MGG-(1 to 20$)$ & Mogi Guaçu, SP, Brazil & 39.4 & 21.2 \\
\hline & CIT-CA-ITP-(1-20) & Itapetininga, SP, Brazil & 45.4 & 23.4 \\
\hline & SGR-FTP-(1 to 20$)$ & Frostproof, FL, USA & 48.2 & 21.6 \\
\hline Mean & & & 44.6 & 21.5 \\
\hline \multirow[t]{3}{*}{ High } & SLG-MGG-(1 to 20$)$ & Mogi Guaçu, SP, Brazil & 46.6 & 22.8 \\
\hline & OCO-ARC-(1 to 20$)$ & Arcadia, FL, USA & 45.3 & 19.2 \\
\hline & STF-FTP-(1 to 20$)$ & Frostproof, FL, USA & 43.0 & 20.2 \\
\hline Mean & $\ldots$ & $\ldots$ & 45.4 & 21.3 \\
\hline $\mathrm{CV}(\%)$ & $\ldots$ & $\ldots$ & 19.9 & 14.3 \\
\hline
\end{tabular}

a Values are means of two assays; benomyl concentration at 0.1 or $1.0 \mu \mathrm{g} / \mathrm{ml}$.

${ }^{\mathrm{b}}$ Benomyl usage. High: benomyl applied every year, often 2 to 3 times per year. Moderate: benomyl applied in most years, but usually not more than once per year. Low: benomyl sprayed from one to three times during the last 5 years. None: no known applications of the fungicide. $\mathrm{CV}=$ coefficient of variance.

${ }^{\mathrm{c}}$ City, state, country.

gloeosporioides. Moderately sensitive isolates of $C$. acutatum apparently must be controlled well by benomyl because this fungicide has been quite effective in field tests and usually outperforms all other products $(13,24)$. Goes and Kimati (7) reported 40 to $85 \%$ inhibition of mycelial growth in isolates of $C$. acutatum at benomyl concentrations from 1 to $2,500 \mu \mathrm{g} / \mathrm{ml}$ and they considered the fungus insensitive to the fungicide. The same authors found no differences in mycelial growth among three isolates of $C$. acutatum from groves with different histories of benomyl usage. In a similar study, $86 \%$ of isolates of $M y$ cosphaerella fijiensis from banana plantations where benomyl was used for approximately 10 years to control Black Sigatoka were resistant to benomyl. No resistance was detected in isolates collected from plantations with no history of benomyl use (16).

Mutations conferring high levels of benomyl resistance appear to be very rare or nonexistent in $C$. acutatum populations. Control failures attributable to resistance never have been reported with $C$. $a c u$ tatum, despite widespread use of the product throughout the Americas. In our surveys in São Paulo and Florida, there was no correlation between sensitivity and history of benomyl usage. Benomyl does not inhibit spore germination nor is it effective in reducing conidia production; apparently, it acts primarily by slowing mycelial growth before or after infection (14). In aqueous solution, benomyl is converted to methyl benzimidazole carbamate (MBC) and butyl isocyanate. However, in practical conditions, benomyl is almost insoluble in water and a considerable part of the fungicide remains on the surface of the plant and converts gradually to MBC (15). We suspect that the greater toxicity at the lower concentration of $0.1 \mu \mathrm{g} / \mathrm{ml}$ than at higher concentrations on conidia germination may be related to the uptake of MBC into the germinating conidia. It is possible that uptake is greater in more dilute solution than in more concentrated solutions.

We did not find an amino acid substitution in the $\beta$-tubulin gene region of isolates of $C$. acutatum that usually confers low to high levels of resistance in other species of

Table 3. Influence of different sources of variation on the relative growth of isolates of Colletotrichum acutatum from citrus groves with different histories of benomyl usage in São Paulo, Brazil and Florida, United States

\begin{tabular}{|c|c|c|c|c|c|c|c|c|c|}
\hline \multirow[b]{2}{*}{ Source of variation } & \multirow[b]{2}{*}{ df } & \multicolumn{4}{|c|}{ Benomyl at $0.1 \mu \mathrm{g} / \mathrm{ml}$} & \multicolumn{4}{|c|}{ Benomyl at $1.0 \mu \mathrm{g} / \mathrm{ml}$} \\
\hline & & MS & Error & $F$ & $P$ & MS & Error & $F$ & $P$ \\
\hline Benomyl usage (B) & 3 & 348.0 & 506.9 & 0.69 & 0.5826 & 16.2 & 71.9 & 0.23 & 0.8763 \\
\hline Country (C) & 1 & 134.6 & 507.4 & 0.27 & 0.6189 & 980.7 & 72.0 & 13.63 & 0.0050 \\
\hline $\mathrm{B} \times \mathrm{C}$ & 3 & 566.7 & 507.5 & 1.12 & 0.3925 & 114.5 & 72.0 & 1.59 & 0.2590 \\
\hline Grove & 9 & 505.3 & 712.7 & 0.71 & 0.6916 & 72.0 & 67.0 & 1.07 & 0.4583 \\
\hline Assay & 1 & 48.1 & 714.6 & 0.07 & 0.8011 & 383.5 & 67.0 & 5.73 & 0.0403 \\
\hline Grove $\times$ assay & 9 & 712.7 & 72.7 & 9.80 & $<0.0001$ & 67.0 & 8.8 & 7.63 & $<0.0001$ \\
\hline Assay $\times$ B & 3 & 377.2 & 715.1 & 0.53 & 0.6744 & 161.8 & 67.0 & 2.42 & 0.1336 \\
\hline Assay $\times \mathrm{C}$ & 1 & 301.0 & 715.7 & 0.42 & 0.5329 & 179.6 & 67.0 & 2.68 & 0.1360 \\
\hline Assay $\times \mathrm{B} \times \mathrm{C}$ & 3 & 26.5 & 715.9 & 0.04 & 0.9898 & 10.4 & 67.0 & 0.16 & 0.9238 \\
\hline
\end{tabular}


pathogenic fungi. Previous studies have demonstrated that $C$. graminicola and $C$. gloeosporioides $\mathrm{f}$. sp. aeschynomene have two $\beta$-tubulin genes, TUB1 and TUB2. Comparison with the amino acid sequences indicated that TUB2 had a high degree of homology to other fungal $\beta$ tubulins (2,3,11). Mutations that confer benomyl resistance have been identified in TUB2 homologs from several fungi, including $C$. gloeosporioides f. sp. aeschynomene (3). Three phenotypes were identified among benomyl-resistant strains of Botrytis cinerea correlated with single pair mutations at codons 198 and 200. These mutations were similar to those identified in benomyl-resistant field strains of other phytopathogenic fungi (27). Among isolates of Tapesia yallundae and T. acuformis, seven phenotypes were identified that were related to benzimidazole sensitivity. All resistant isolates had a mutation at codon 198,200 , or 240 of the $\beta$ tubulin gene fragment and the different phenotypes for resistance were correlated with particular amino acid substitutions (1). Laboratory-induced, benomyl-resistant strains of $V$. inaequalis showed mutations on seven different codons compared with the naturally resistant strains. However, those mutations might interfere with fitness, which is evidenced by their low persistence in field populations (10). Similarly, two of the laboratory resistant isolates of $C$. gloeosporioides sequenced did not have the amino acid point mutation in the region that usually confers resistance to benomyl in naturally occurring mutants.

Northern hybridizations showed TUB2 expression in ungerminated conidia, conidiating mycelia, and vegetative mycelia of C. gloeosporioides f. sp. aeschynomene (2). However, transcripts of the divergent $\beta$-tubulin gene, TUB1, were detected in conidiating mycelia but not ungerminated conidia or vegetative mycelia. Expression of the TUB1 gene in C. gloeosporioides $\mathrm{f}$. sp. aeschynomene and $C$. graminicola showed fundamental differences between those two species and it could be interesting to investigate this gene in C. acutatum.

The manufacture and distribution of benomyl has been discontinued recently. However, other benzimidazole fungicides, such as carbendazim and thiophanate methyl, are registered for use on citrus in many areas $(4,19)$. These products also break down to MBC; therefore, C. acutatum should respond to them in the same manner as to benomyl. Despite the relatively low sensitivity of $C$. acutatum to the product, benomyl continues to provide good control of postbloom fruit drop. The risk of development of resistance seems minimal because we were unable to select or recover highly resistant isolates. The basis for the low sensitivity of $C$. acutatum to benomyl remains unclear, but is not associated with the region of the $\beta$-tubulin gene responsible for high or moderate resistance in C. gloeosporioides and other fungi. Only a portion of the $\beta$-tubulin was sequenced; therefore, it might be possible that a mutation is present in a different portion of the gene that was not sequenced or $C$. acutatum contains a divergent $\beta$ tubulin gene.

\section{ACKNOWLEDGMENTS}

We thank the growers who allowed us to collect isolates in Brazil (Citrovita Agrícola, Fazenda Sete Lagoas, Grupo Fischer, Cia Agrícola de Botucatu, Fazenda Real) and Florida (Via Tropica, Ben Hill Griffin Inc., Collier Groves, Maran, Albritton,

Table 4. Point mutations and deduced amino acid substitutions in the partial sequence of the $\beta$-tubulin gene of isolates of Colletotrichum spp. with different phenotypic responses to benomyl

\begin{tabular}{lllccc}
\hline & & & & \multicolumn{2}{c}{ Amino acid in position } \\
\cline { 5 - 6 } Isolate & \multicolumn{1}{c}{ Species } & Host & Response $^{\mathbf{a}}$ & $\mathbf{1 9 8}$ & $\mathbf{2 0 0}$ \\
\hline Maran & C. acutatum & Citrus & MR & Glu & Phe \\
CS-1 & C. acutatum & Citrus & MR & Glu & Phe \\
GND-2 & C. acutatum & Citrus & MR & Glu & Phe \\
OCO-ARC-1 & C. acutatum & Citrus & MR & Glu & Phe \\
GLB-3 (S) & C. gloeosporioides & Citrus & S & Glu & Phe \\
TH-4 (S) & C. gloeosporioides & Citrus & S & Glu & Phe \\
DIL-ARK-2 (S) & C. gloeosporioides & Citrus & S & Glu & Phe \\
GLB-3 (R) & C. gloeosporioides & Citrus & LSR & Glu & Phe \\
TH-4 (R) & C. gloeosporioides & Citrus & LSR & Glu & Phe \\
DIL-ARK-2 (R) & C. gloeosporioides & Citrus & LSR & Ala & Phe \\
MIN-ER3-MIA & C. gloeosporioides & Citrus & NR & Ala & Phe \\
Blueb-1 & C. gloeosporioides & Blueberry & NR & Ala & Phe \\
\hline
\end{tabular}

a Phenotic response: $\mathrm{MR}=$ moderate resistance to benomyl (growth inhibited more than $50 \%$ at 1.0 $\mu \mathrm{g} / \mathrm{ml}) ; \mathrm{S}=$ sensitive; LSR = laboratory selected resistant; $\mathrm{NR}=$ naturally resistant.
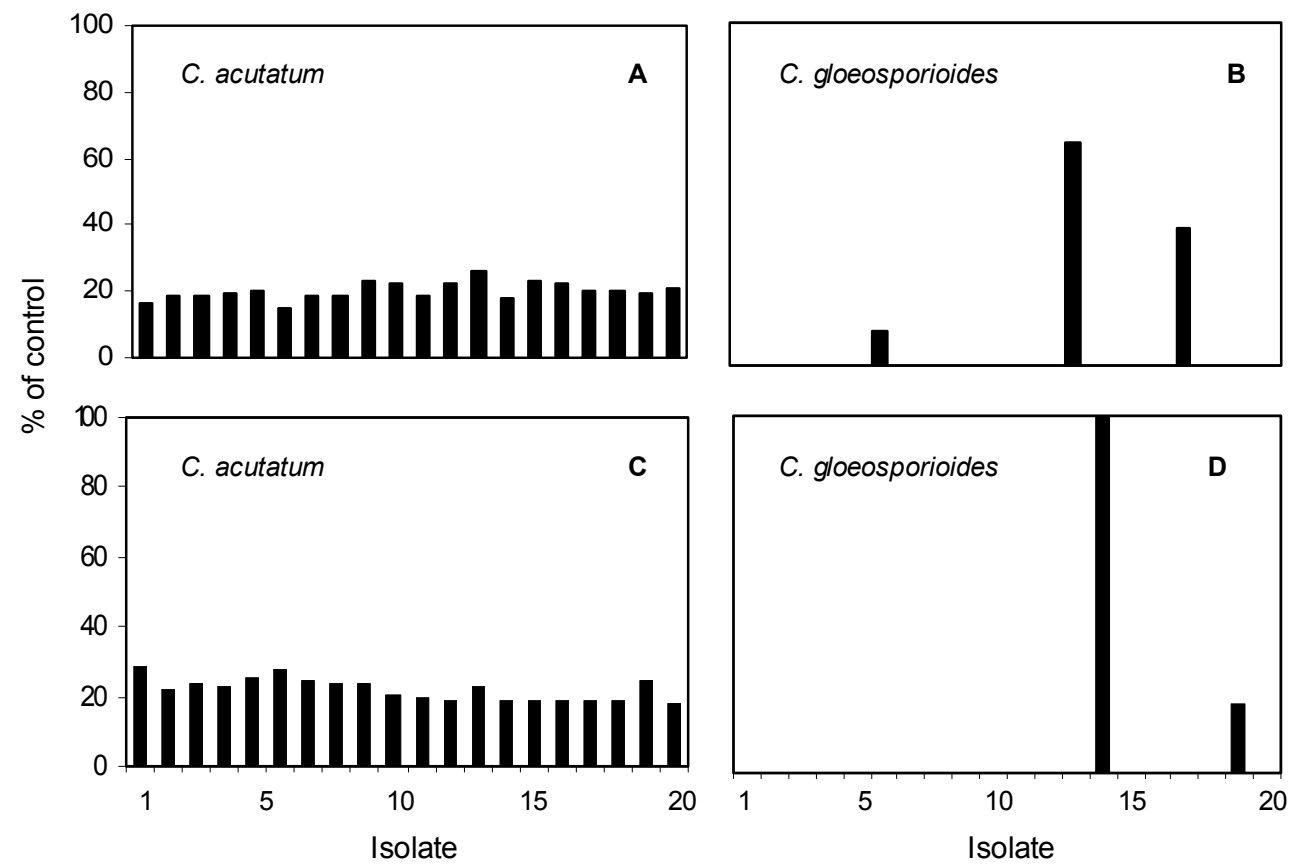

Fig. 3. The range of sensitivity of mycelial growth of individual isolates of $\mathbf{A}$ and $\mathbf{C}$, Colletotrichum acutatum and $\mathbf{B}$ and $\mathbf{D}$, C. gloeosporioides within two groves: A and B, SRL-FTP (benomyl never used) and $\mathbf{C}$ and $\mathbf{D}$, SLG-MGG (high use of benomyl) on medium amended with benomyl at $1.0 \mu \mathrm{g}$ a.i./ml. 
Orange-co); R. C. Littell, Statistics Department, University of Florida, Gainesville, for assistance with the analysis of the data; and C. Geanangel, R. F. da Silva, and A. F. Angêlla for technical assistance.

\section{LITERATURE CITED}

1. Albertini, C., Gredt, M., and Leroux, P. 1999. Mutations on the $\beta$-tubulin gene associated with benzimidazole resistance in the cereal eyespot fungi Tapesia yallundae and Tapesia acuformis. Pestic. Biochem. Physiol. 64:1731.

2. Buhr, T. L., and, Dickman, M. B. 1993. Isolation and characterization of a $\beta$-tubulin-encoding gene from Colletotrichum gloeosporioides f. sp. aeschynomene. Gene 124:121-125.

3. Buhr, T. L., and Dickman, M. B. 1994. Isolation, characterization, and expression of a second $\beta$-tubulin-encoding gene from Colletotrichum gloeosporioides f. sp. aeschynomene. Appl. Environ. Microbiol. 60:4155-4159.

4. Compêndio de Defensivos Agrícolas. 1999. Guia prático de produtos fitossanitários para uso agrícola. Organização Andrei Editora. São Paulo, SP, Brazil.

5. Davidse, L. C. 1986. Benzimidazole fungicides: Mechanism of action and biological impact. Annu. Rev. Phytopathol. 24:43-65.

6. Goes, A., and Kimati, H. 1994. Efeito de benomyl no crescimento micelial de Colletotrichum gloeosporioides, agente causal da queda prematura de frutos jovens de citros. Summa Phytopathol. 20:46.

7. Goes, A., and Kimati, H. 1998. Colletotrichum acutatum, agente causal da queda prematura dos frutos citricos: resistente ou insensivel a benomyl? Summa Phytopathol. 24:246-253.

8. Griffee, P. J. 1973. Resistance to benomyl and related fungicides in Colletotrichum musae. Trans. Br. Mycol. Soc. 60:887.

9. Hewitt, H. G. 1998. Fungicide resistance.
Pages 155-181 in: Fungicides in Crop Protection. H. G. Hewitt, ed. Centre for Agriculture and Biosciences International. Wallingford, UK.

10. Koenraadt, H., Somerville, S. C., and Jones, A. L. 1992. Characteristics of mutations in the beta-tubulin gene of benomyl-resistant field strains of Venturia inaequalis and other plant pathogenic fungi. Phytopathology 82:13481354.

11. Panaccione, D. G., and Hanau, R. M. 1990. Characterization of two divergent $\beta$-tubulin genes from Colletotrichum graminicola. Gene 86:163-170.

12. Peever, T. L., Canihos, Y., Olsen, L., Ibañez, A., Liu, Y.-C., and Timmer, L. W. 1999. Population genetic structure and host specificity of Alternaria spp. causing brown spot of Minneola tangelo and rough lemon in Florida. Phytopathology 89:851-860.

13. Peres, N. A. R., Souza, N. L., and Timmer, L. W. 2000. Postbloom fruit drop in Brazil and Florida: occurrence and control by fungicides. Proc. Int. Soc. Citricult. 6:1051-1052.

14. Peres, N. A. R., Souza, N. L., Zitko, S. E., and Timmer, L. W. 2002. Activity of benomyl for control of postbloom fruit drop of citrus caused by Colletotrichum acutatum. Plant Dis. 86:620-624.

15. Picinini, E. C. 1994. Fungicidas benzimidazoles. 1994. Rev. Anu. Patol. Plantas 2:357409.

16. Romero, R. A., and Sutton, T. B. 1998. Characterization of benomyl resistance in $M y$ cosphaerella fijiensis, cause of black Sigatoka of banana, in Costa Rica. Plant Dis. 82: 931934.

17. Sonoda, R. M., and Pelosi, R. R. 1988. Outbreak of citrus postbloom fruit drop caused by Colletotrichum gloeosporioides from lesions on citrus blossoms in the Indian River of Florida. Proc. Fla. State Hortic. Soc. 101:36-38.
18. Timmer, L. W. 1998. Evaluation of fungicides for control of postbloom fruit drop by Colletotrichum acutatum. Fungic. Nematicide Tests 53:335.

19. Timmer, L. W., ed. 2003. 2003 Florida Citrus Pest Management Guide. Univ. Fla. Coop. Ext. Serv. Publ. No. SP-43, Gainesville.

20. Timmer, L. W., Agostini, J. P., Zitko, S. E., and Zulfiqar, M. 1994. Postbloom fruit drop, an increasingly prevalent disease of citrus in the Americas. Plant Dis. 78:329-334.

21. Timmer, L. W., and Brown, G. E. 2000. Biology and control of anthracnose diseases of citrus. Pages 300-316 in: Host Specificity, Pathology, and Host-Pathogen Interactions of Colletotrichum. D. Prusky, S. Freeman, and M. B. Dickman, eds. American Phytopathological Society Press, Inc., St. Paul, MN.

22. Timmer, L. W., Brown, G. E., and Zitko, S. E. 1998. The role of Colletotrichum spp. in postharvest anthracnose of citrus and survival of $C$. acutatum on fruit. Plant Dis. 82:415-418.

23. Timmer, L. W., Garnsey, S. M., and Graham, J. H., eds. 2000. Pages 37-38 in: Compendium of Citrus Diseases. American Phytopathological Society Press, Inc., St. Paul, MN.

24. Timmer, L. W., and Zitko, S. E. 1996. Evaluation of a model for prediction of postbloom fruit drop of citrus. Plant Dis. 80:380-383.

25. Whiteside, J. O. 1980. Tolerance of $M y$ cosphaerella citri to benomyl in Florida citrus groves. Plant Dis. 64:300-302.

26. Whiteside, J. O. 1980. Detection of benomyl tolerant strains of Elsinoe fawcettii in Florida citrus groves and nurseries. Plant Dis. 64:871872.

27. Yarden, O., and Katan, T. 1993. Mutations leading to substitutions at amino acids 198 and 200 of beta-tubulin that correlate with benomyl-resistance phenotypes of field strains of Botrytis cinerea. Phytopathology 83:14781483 . 